\title{
Parity and Periparturient Period Affects Galectin Gene Expression in Holstein Cow Blood
}

\author{
Emmanuel K Asiamah \\ Dept. of Applied Science and Technology (Bioscience), North Carolina A\&T State University, \\ Greensboro, NC USA \\ Tel: 1-779-225-9580Ｅ-mail: ekasiama@aggies.ncat.edu
}

\begin{abstract}
Dr. Sarah Adjei-Fremah
Department of Animal Sciences, North Carolina A\&T State University, Greensboro, NC USA

Tel: 1-605-651-5221Ｅ-mail: sadjeifr@ncat.edu
\end{abstract}

Kingsley Ekwemalor

Dept. of Applied Science and Technology (Bioscience), North Carolina A\&T State University, Greensboro, NC USA

Tel: 1-336-405-6094Ｅ-mail:kaekwema@aggies.ncat.edu

Dr. Lorraine Sordillo

College of Veterinary Medicine, Michigan State University

Tel: 1- 517-432-8821 E-mail: sordillo@msu.edu

Dr. Mulumebet Worku (Corresponding author)

Department of Animal Sciences, North Carolina A\&T State University, Greensboro, NC USA

Tel: 1-336-285-4816 E-mail: worku@ncat.edu

Received: April 13, 2018 Accepted: May 24, 2018 Published: May 26, 2018

Doi: 10.5296/jab.v6i2.13017ＵRL: http://doi.org/10.5296/jab.v6i2.13017 


\section{Abstract}

The periparturient period in dairy cows is a crucial time influencing health, milk production and fertility. Galectins are receiving interest as therapeutic targets because of their roles in immune signaling pathways. The aim of this study was to evaluate the expression and modulation of galectin genes in periparturient cows with different parities. Twelve periparturient Holstein Friesian cows were grouped into 3 parities $\left(1^{\text {st }}\right.$ parity, $2^{\text {nd }}$ parity, $3^{\text {rd }}$ parity) $(\mathrm{N}=4)$. Blood was taken during the periparturient period including 2 weeks close to parturition (close-up), and 7 days after parturition(c+7) in Paxgene tubes. Total RNA was isolated, reverse-transcribed to cDNA. With the use of Primer 3 online tool, specific primers (forward and reverse) for cow galectins $L G A L S-1,2,3,4,7,8,9,12,15$, GAPDH and $\beta$-actin were designed. Transcription of galectins was evaluated using Real-time PCR. Fold change in transcript abundance was calculated using the Livak method. GAPDH and $\beta$-actin served as internal controls. Enzyme-linked Immunosorbent Assay (ELISA) was used to detect and determine the concentrations of Galectins(Gal) in the plasma. All galectins tested were differentially expressed. LGALS1 and LGALS15 were transcribed only during late gestation, but undetected postpartum regardless of parity. Gal-1, $-2,-4,-8$ and -9 concentrations in plasma were high in periparturient cows compared to far-off cows. Gal9 concentration increased postpartum. Gal-2, Gal-3 and-Gal-12 concentrations were reduced in plasma postpartum compared to far-off cows. This study supports the idea that galectin signatures may be useful biomarkers and drug targets in dairy cows, especially during the periparturient period.

Keywords: Galectins, Gene expression, Periparturient, Parity

\section{Introduction}

The recognition of the importance of the period from late pregnancy until the adaptation phase of early lactation has led to the development of the concept of the periparturient period, which is commonly defined as the period from 3 weeks before to 3 weeks after calving(Esposito et al., 2014). The periparturient period for dairy cows is characterized by significant metabolic and immunologic changes. These metabolic and immunologic changes occur concurrently with a high incidence of infectious diseases in dairy cows. An estimated 30 to $50 \%$ of cows are reported to experience health disorders during the periparturient period, and the majority (75\%) of infectious disease and metabolic disorders in dairy cows occur during this time (Sordillo \& Mavangira, 2014). Health disorders during the periparturient period impact the productive efficiency of the cows (Crookenden et al., 2016). For this reason, there have been many studies to better understand the underlying causes of both metabolic and infectious diseases around the time of parturition in order to design more effective management practices to reduce cow health disorders (Adjei-Fremah et al., 2016; Sordillo \& Mavangira, 2014; Zhang et al., 2015). Previous studies have indicated that the high incidence of disease during the periparturient period is linked to the changes in hormone and protein concentrations in blood around this time(Heiser et al., 2015). Also, there is evidence that age (Oltenacu \& Ekesbo, 1994) and parity (Hiromichi et al., 2009) have an effect on susceptibility to infectious diseases during the periparturient period. Genes involved in inflammation and mediation of the inflammatory responses have been reported to be altered 
in dairy cows during the periparturient period ( Crookenden et al., 2016).

Galectins, lectins with an affinity for $\beta$-galactosides have been shown to be differentially expressed in the endometrium of humans, murine and ruminants (Masahiro, Hashiba, Junko, \& Okuda, 2015; Nio-Kobayashi et al., 2016; L. A. Okumu et al., 2011; Osei et al., 2017). They have been postulated to play key roles in endometrial immunity since they are differentially expressed in the endometrium, ovaries, and placenta around the time of parturition (Walker et al., 2010). For instance, LGALS1 is differentially expressed between normal and pathologically altered placentas in human. Also, in cows, LGALS3 is detected in the ovary, oviduct, uterus, and cervix and is postulated to be involved in mucosal defense. Galectins could be key players in immunity of cows, especially during the periparturient period. However, the role of galectins in cow blood postpartum cow disease has not been explored. Galectins have been known to act as PRRs as well as PAMPs that orchestrate immune responses according to the level of pathogenicity of the invading microorganisms (Sato, St - Pierre, Bhaumik, \& Nieminen, 2009; van Kooyk \& Rabiinovich, 2008). The binding of some galectin to microorganism-specific glycans or host-like glycans on microorganisms can initiate immune responses, which leads to clearance of the microorganism. Moreover, previous studies have implicated some galectins in parasite or pathogen establishment through biomimicry(Souza et al., 2015). The microbe's recognition by the vector or host galectins promotes its adhesion, host cell entry, or infection persistence, in addition to modulating the host's immune responses. Thus, these pathogens and parasites would "subvert" the roles of the host or vector galectins as PRRs, to attach to or gain entry into their cell (Bianchi, 2007; Fermino et al., 2011).

All these functions make galectins promising molecules to be involved in the immunological regulation during the peripartal period. The expression of galectins has been extensively investigated so far in the reproductive organs of diverse mammals including cows and are known to be involved in the regulation of endometrial immunity (Okumu et al., 2011; Popovici et al., 2005; Sheldon et al., 2009). However, little is known about its expression in the blood of the cow (L. A. Okumu et al., 2011). Understanding galectin expression during the periparturient period will contribute to the design of control strategies and biotherapeutics to alleviate immunosuppression in periparturient ruminants.

The aim of the study is, therefore, to evaluate the expression and modulation of galectin genes in periparturient cows with different parities.

\section{Materials and Methods}

\subsection{Animals}

Twelve Holstein Friesian periparturient $\left(1^{\text {st }}\right.$ parity, $2^{\text {nd }}$ parity, $\left.3^{\text {rd }}\right)(\mathrm{N}=4)$ cows from a commercial dairy herd in Michigan were used. Far-off $\operatorname{cows}(\mathrm{N}=4)$ from North Carolina A\&T State Dairy farm were used as controls. None of the animals exhibited any evidence of disease or received medications during the 4 -week period prior to blood sampling. All protocols for the handling of the animals were approved by the Institutional Animal Care and Use Committee.

\subsection{Blood Sampling}

Complete details of blood sampling have been reported elsewhere (Asiamah et al., 2016; 
Ekwemalor et al., 2016). Briefly, whole blood $(2.5 \mathrm{ml})$ was collected aseptically from the jugular vein of the animals into PAXGene tubes. The tubes were gently mixed and placed on ice immediately after collection. The samples were shipped overnight to the Laboratory of Animal Genomic Diversity and Biotechnology at North Carolina A\&T State University for further analysis.

\subsection{Isolation of Total RNA and cDNA Synthesis}

Total RNA was isolated using Trizol according to the manufacturer's instructions (Sigma-Aldrich St. Louis, MO). The appropriate precautions were used to avoid RNase contamination throughout the entire procedure (Adjei-Fremah et al., 2016; Worku et al., 2016). The RNA concentration (ng/ $\mu \mathrm{l})$ and purity (260/280) were assessed using a Nanodrop Spectrophotometer ND 1000 (Thermo Scientific Inc., Waltham, MA). Total RNA was pipetted into an RNA 6000 Nano LabChip ${ }^{\circledR}$ (Agilent Technologies, DE) and RNA integrity was determined using Bioanalyzer following manufacturer's protocol (Agilent Technologies, DE). Complimentary DNA (cDNA) synthesis was performed with $500 \mathrm{ng} / \mu \mathrm{l}$ RNA (purity $260 / 280=1.8, \mathrm{RIN}=7$ ). Retroscript kits (Bio-rad Laboratories, CA) were used to synthesize cDNA for real-time Polymerase chain reaction.

\subsection{Gene Expression Profiling of Galectins}

With the use of Primer-3 online tool, Forward and reverse primers for cow galectins LGALS1, 2, 3, 4, 7, 8, 9, 12 and 15 were designed commercially. Primers specific for $L G A L S 1$, LGALS2, LGALS3, LGALS4, LGALS7, LGALS8, LGALS9, LGALS12, LGALS15, GAPDH and $\beta$ actin were purchased from MWG, Biotech Huntsville AL (Table 1). Beta-actin and GAPDH were used as internal controls and for normalization.

Table 1. Sequences of primers used

\begin{tabular}{lllll}
\hline $\begin{array}{l}\text { Accession } \\
\text { number }\end{array}$ & Gene & Primer & Sequence 5'>3' & $\begin{array}{c}\text { Expected } \\
\text { Product } \\
\text { Size (bp) }\end{array}$ \\
\hline NM_175782 & LGALS1 & Forward & GGCAAAGACGACAACAACCT & 189 \\
& & Reverse & GGTTAGGTCCGTCTGGTTGA & \\
NM_001075494 & LGALS2 & Forward & CCTCACCAGAGAGCAAGACC & 181 \\
& & Reverse & TGGAAAACACCACAGTTGGA & \\
NM_001102341 & LGALS3 & Forward & GAATGATGTCGCCTTCCACT & 165 \\
& & Reverse & TCAGGTTCAACCAGCACTTG & \\
NM_001034768.2 & LGALS4 & Forward & ATTCACGACTCCTGCAGCTT & 215 \\
& & Reverse & CCCCACCTCGAAGTTTACAA & \\
XM_010826300 & LGALS7 & Forward & TCTACGTGAACCTGCTGTGC & 236 \\
& & Reverse & CCGGAAGTGGTGTACTCAG & \\
NM_001045954.2 & LGALS8 & Forward & TCGTGATCATGGTCCTGAAA & 232 \\
& & Reverse & TGTGACTCGCCAGACTTTTG &
\end{tabular}


NM_001015570.3 LGALS9

Forward

Reverse

TGTACCCCTCCAAGAGCATC

2018, Vol. 6, No. 2

233

XM_015467485LGALS12 Forward CAGCTGATCCCACTCTCCTC

Reverse AATGCCAGGCTCTCAGAAGA

\subsection{Real-Time PCR}

Real-time PCR was performed on the CFX Connect real-time system (Bio-rad Laboratories, CA) as described by (Ekwemalor et al., 2016). The PCR reaction mixture consisted of template, primer (1ul), intercalating dye SYBR Green (10ul). All samples were carried out in duplicate $20-\mu 1$ reactions in $96-w e l l$ plates, and a negative control with no cDNA template was included in every run. The PCR conditions used was: $95{ }^{\circ} \mathrm{C}$ for 15 seconds for denaturing, $60{ }^{\circ} \mathrm{C}$. for 30 seconds for primer annealing, and $72{ }^{\circ} \mathrm{C}$ for elongation (Asiamah et al., 2016).

Specificity of the amplicon products was confirmed by visual inspection of melting curves. Real-time PCR data were analyzed using the Livak's method(Livak \& Schmittgen, 2001). Gene expression was normalized using the geometrical mean of the housekeeping genes, $G A P D H$, and $\beta$ actin. The housekeeping genes (GAPDH and $\beta$ actin) and samples from far-off cows were used to determine the $\Delta \Delta \mathrm{Ct}$ (Worku and Morris, 2009; Asiamah et al., 2017). Where $\Delta \mathrm{Ct}=$ (Target genes $\left.{ }_{\mathrm{c}+7}-\mathrm{GAPDH} / \beta_{\text {actin }}{ }_{\mathrm{c}+7}\right)-\Delta \mathrm{Ct}$ (Target genes c.u $_{-}$ GAPDH $/ \beta$ actin $\left._{\text {c.u }}\right)$. Fold change $=2^{(-\Delta \Delta \mathrm{Ct})}$.

\subsection{Agarose Gels Electrophoresis}

Amplified PCR products were run on $1 \%$ agarose gel using $5 \mu$ of amplified cDNA and $1 \mu \mathrm{l}$ of six times loading dye (Thermo Scientific) at 100 volts for 30 minutes. Gels were stained with $1 \mu \mathrm{l} / \mathrm{ml}$ ethidium bromide, washed and visualized using Bio-Rad gel documentation

system (Bio-Rad Laboratories, Hercules, CA). The product sizes were compared to the expected product sizes in Table 1.

\subsection{Evaluation of the Concentration of Total Plasma Protein}

Total protein concentrations in plasma harvested from far off cows $(n=4)$ and periparturient cows (close-up (c.u) and seven days after calving $(\mathrm{c}+7)$ were measured using the bicinchoninic acid assay (BCA) following the manufacturer's instructions (Thermo Scientific $^{\mathrm{TM}}$ Pierce) as previously described by Adjei-Fremah et al., (2015; 2018), and Asiamah (2015) . A standard curve was used to calculate the concentrations.

\subsection{Evaluation of Galectin Secretion}

The concentrations of secreted Galectins (Gal) $-1,-2,-3,-4,-7,-8,-9,-12$ in plasma were determined $(100 \mu \mathrm{l})$ using commercial bovine ELISA kits (Gal-1 catalog no. MBS2882620, Gal-2 catalog no. MBS033680, Gal-3 catalog no. MBS017323, Gal-4 catalog no. MBS028694 Gal-8 catalog no. MBS041856, Gal-9 catalog no. MBS033074, Gal-12 catalog no. MBS032400; My BioSource $\left.{ }^{\circledR}\right)$ according to the manufacturer's instructions. Absorbance was measured at $450 \mathrm{~nm}$ using microplate reader (Bio Tek). A standard curve was used to 
determine the concentration.

Briefly, $100 \mu \mathrm{L}$ of each standard and sample was added to appropriate wells. Wells were covered and incubated for 2.5 hours at room temperature with gentle shaking. The solution was discarded, and the plate was washed 4 times with 1X Wash Buffer. One hundred (100) $\mu \mathrm{L}$ of $1 \mathrm{X}$ prepared biotinylated antibody was added to each well and Incubated for 1 hour at room temperature with gentle shaking. The solution was discarded and wash step repeated. One hundred (100) $\mu \mathrm{L}$ of prepared Streptavidin-HRP was added to each well and incubated for 45 minutes at room temperature. The solution was discarded, and the wash step was repeated. One hundred (100) $\mu \mathrm{L}$ of TMB Substrate was added to each well and incubated for 30 minutes at room temperature in the dark with gentle shaking. Absorbance was measured at $450 \mathrm{~nm}$ using a microplate reader (Bio Tek). A standard curve was then used to determine the galectin concentration. The sensitivity of the assays was $0.1 \mathrm{ng} / \mathrm{ml}$, the detection range were: Gal1; 0.31ng/ml \& 20.0ng/ml, Gal2; $0.625 \mathrm{ng} / \mathrm{ml} \& 20 \mathrm{ng} / \mathrm{ml}$., Gal3; $10 \mathrm{ng} / \mathrm{ml} \& 0.156 \mathrm{ng} / \mathrm{ml}$, Gal4; $0.25 \mathrm{ng} / \mathrm{ml} \& 8 \mathrm{ng} / \mathrm{ml}$, Gal8; $0.5 \mathrm{ng} / \mathrm{ml} \& 16 \mathrm{ng} / \mathrm{ml}$. Gal9; $.625 \mathrm{ng} / \mathrm{ml} \& 20 \mathrm{ng} / \mathrm{ml}$, Gal12; $31.2 \mathrm{pg} / \mathrm{ml} \& 1000 \mathrm{pg} / \mathrm{ml}$. Both intraassay CV (\%) and inter-assay CV (\%) for all assays was less than $15 \%$. [CV $(\%)=\mathrm{SD} /$ mean $\times 100]$.

\subsection{Statistical Analysis}

Real-time PCR data were analyzed using Livak's method. Housekeeping genes and samples from far off cows were used to determine the $\Delta \Delta \mathrm{Ct}$, as described above. Data for total protein concentration and galectins concentrations were analyzed with the Proc GLM procedure of SAS 9.4 (SAS Institute Inc., Cary, NC). All least squares means were compared using the PDIFF statement of SAS 9.4(SAS Institute Inc.). Significant differences were declared at $\mathrm{P}<$ 0.05 .

\section{Results}

\subsection{Fold change in Galectin Expression}

All galectin genes tested were expressed. LGALS1 and LGALS15 were expressed only prepartum but not postpartum. This was observed at all 3 parities. $L G A L S 2$, however, was not detected in $1^{\text {st }}$ parity cows but present in $2^{\text {nd }}$ parity and $3^{\text {rd }}$ parity cows. LGALS2 increased 2 folds in $2^{\text {nd }}$ parity cows but decreased 5 folds in $3^{\text {rd }}$ parity cows. LGALS4 was only detected close to parturition in $1^{\text {st }}$ and $3^{\text {rd }}$ parity cows and decreased 10 folds in $2^{\text {nd }}$ parity cows after parturition. $L G A L S 7$ decreased 2.5 and 3.3 folds respectively in $1^{\text {st }}$ and $2^{\text {nd }}$ parity cows after parturition but was not detected in $3^{\text {rd }}$ parity cows after parturition. LGALS9 was increased 2.1 and 3.4 folds in $1^{\text {st }}$ and $2^{\text {nd }}$ parity cows respectively. In $3^{\text {rd }}$ parity cows, however, LGALS9 decreased 2.5 folds. (Table 2). LGALS12 was not detected in $1^{\text {st }}$ parity cows postpartum but was increased 3.3 folds postpartum in $2^{\text {nd }}$ parity cows. It was however detected in $3^{\text {rd }}$ parity cows only 7 days postpartum (Table 2) 
Table 2. Fold changes in Galectin gene expression at 3 different parities

\begin{tabular}{llll}
\hline Galectins Transcripts & Parity 1 & Parity 2 & Parity 3 \\
\hline LGALS2 & ND & $2.0^{*}$ & -5.0 \\
LGALS3 & -2.5 & $2.0^{*}$ & -10 \\
LGALS4 & c.u only & -10.0 & c.u only \\
LGALS7 & -2.5 & -3.3 & c.u only \\
LGALS9 & $2.1^{*}$ & $3.4^{*}$ & -2.5 \\
LGALS12 & c.u only only & $3.3^{*}$ & c. + 7only \\
\hline
\end{tabular}

Note $^{*}=$ fold change $\geq 2$ is considered significant, $\mathrm{ns}=$ fold change $<2, \mathrm{ND}=$ absent in close-up and $\mathrm{c}+7$, c.u only $=$ gene was only found in close-up samples but not in $\mathrm{c}+7, \mathrm{c}+7$ only $=$ gene was only found in c+7 samples but not in close-up samples.

\subsection{Amplified Galectins}

All Galectins tested were expressed in cow blood and could be visualized on a $1 \%$ agarose gel at the expected molecular weights (Table1) (Figure 1).

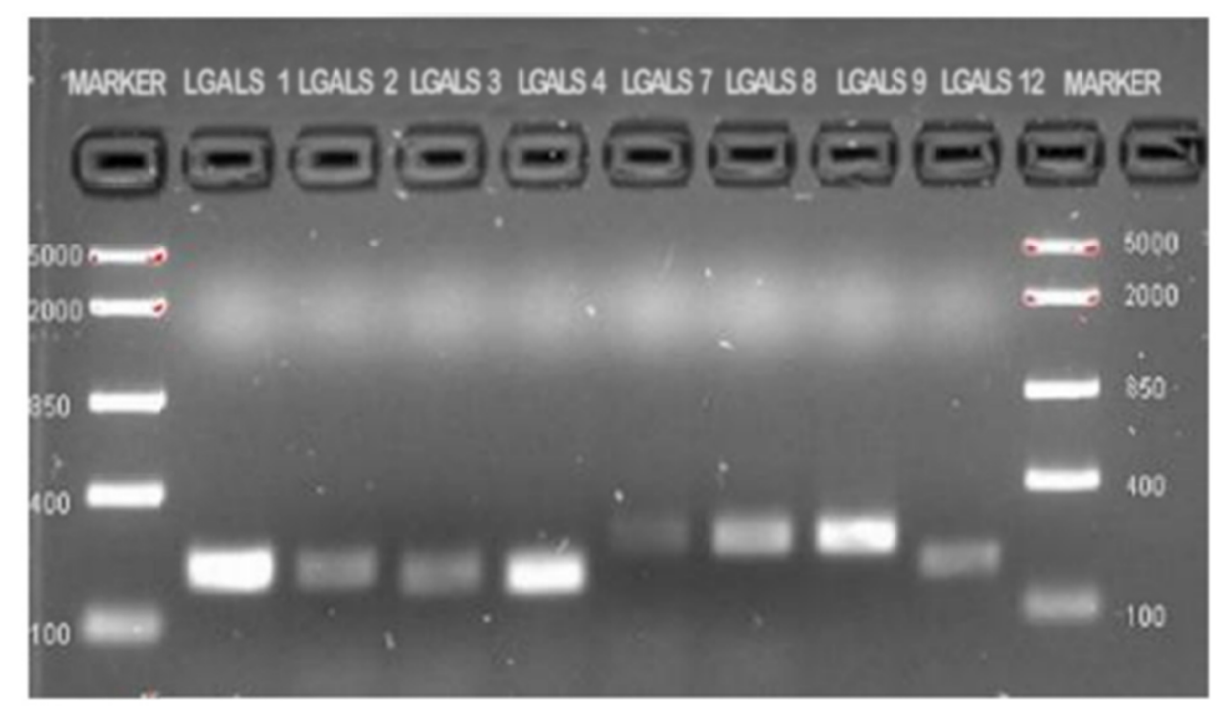

Figure 1. Molecular Weights of Amplified Galectin products in 1\% agarose gel

From left to right: M: Marker (100-5000bp), LGALS1 (189bp), LGALS2 (181bp), LGALS3 (165bp), LGALS4 (215bp), LGALS7 (236bp), LGALS8 (232bp), LGALS9 (233bp), LGALS12 (176bp) and M: Marker (100-5000bp).

\subsection{Total Plasma Protein Concentration}

Protein levels in far-off cows were higher $(4256 \mathrm{ng} / \mathrm{ml})$ compared to the periparturient cows (2443.5 ng/ml) However, protein concentrations did not change 7 days after parturition compared to 2 weeks before parturition (close up=2437 ng/ml and 7 days after parturition $=2450 \mathrm{ng} / \mathrm{ml})(\mathrm{p}>0.05)$ (Figure 2). 
Total protein

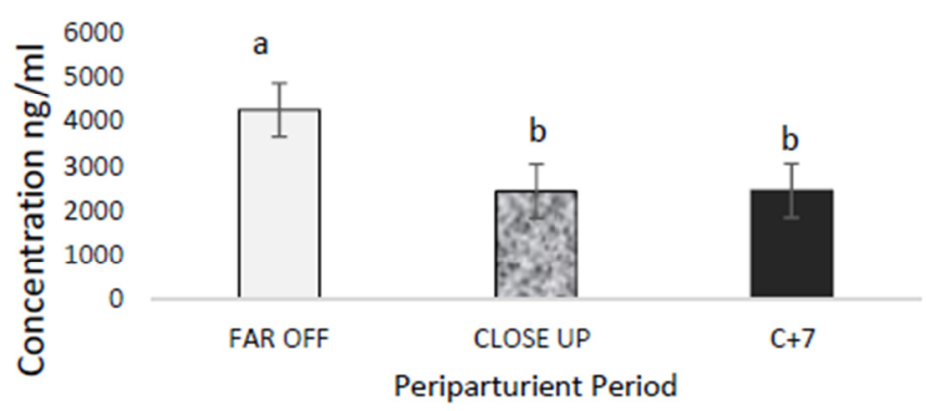

Figure 2. Total protein concentration in Plasma

Plasma was harvested from Far-off cows, close up ( 2 weeks to parturition) cows and $\mathrm{C}+7$ cows ( 7 days after parturition) ( $\mathrm{n}=4$ per group). Plasma from Far-off cows served as controls.

Means with the same letter are not significantly different from each other ( $\mathrm{P}>0.05$ GLM followed by PDIFF). Error lines represent the \pm standard deviation of the mean.

\subsection{Periparturient period had an effect on Galectin concentration in Plasma}

All galectins tested were secreted in plasma. Gal-1, - 4, -8 and -9 are increased in plasma during the periparturient period compared to far off cows. Gal-9 was also increased in C+7 cows compared to close up cows. Gal $-2,-3$ and -12 were reduced during the periparturient period compared to far off cows (Figure 3 ).

(A)

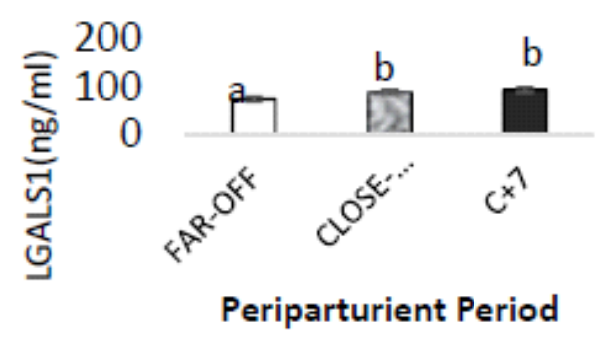

(C)

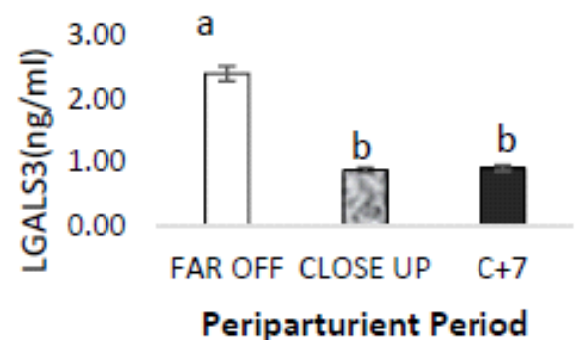

(B)

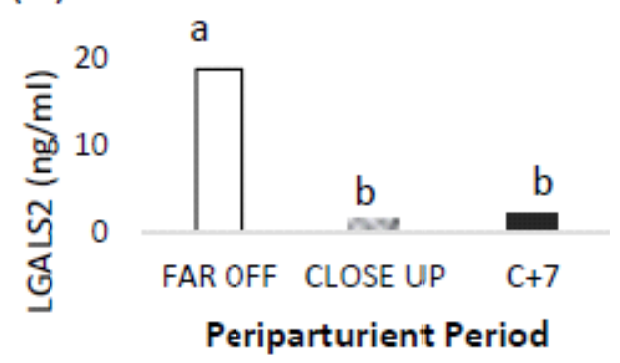

(D) Gal4

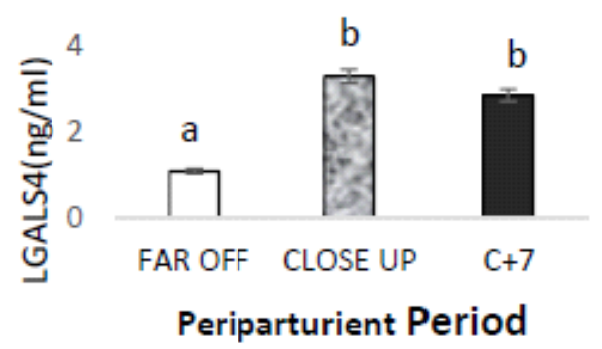




\section{(E)}

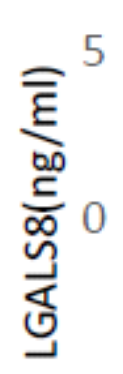

Gal8

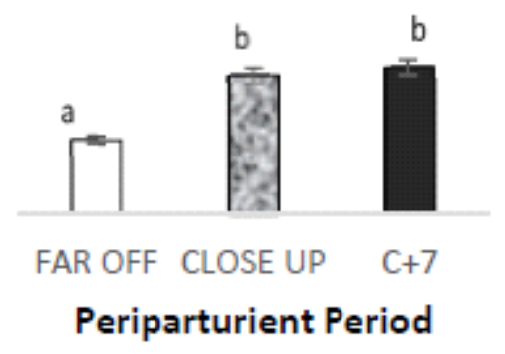

( $F)$

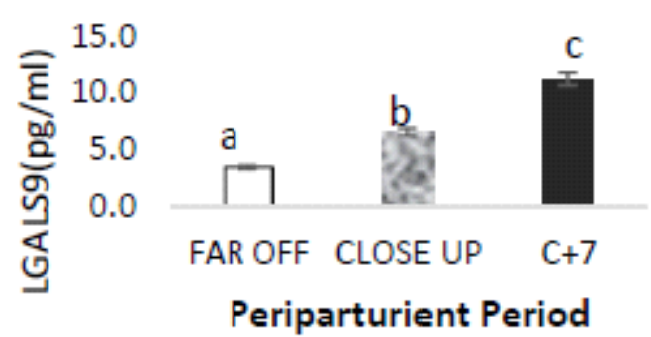

(G) Gal12

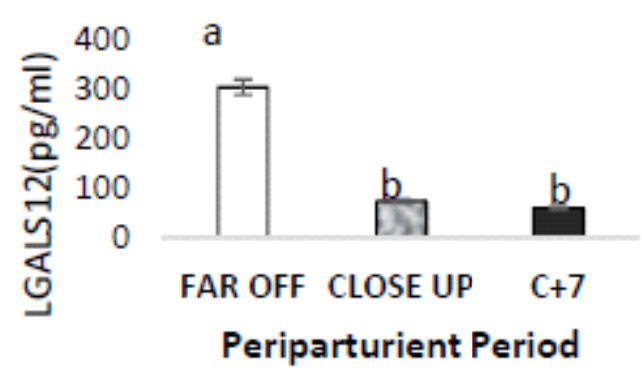

Figure 3. Galectin Concentrations in Plasma

(A)Gal1 (b)Gal2 (C)Gal3 (D)Gal4 (E) Ga8 (F) Gal9 (G) Gal12. Plasma was harvested from. Far-off cows, close up ( 2 weeks to parturition) cows and $\mathrm{C}+7$ cows ( 7 days after parturition) ( $\mathrm{N}=4$ per group). Plasma from Far-off cows served as controls. Means with the same letter are not significantly different from each other ( $\mathrm{P}>0.05$ GLM followed by PDIFF). Error lines represent the \pm standard deviation of the mean.

\section{Discussion}

It is widely accepted that around parturition, cows experience a period of immunosuppression (Kehrli et al., 1989). The combined outcome of immune and metabolic dysfunction during the periparturient period makes the cows more susceptible to infectious diseases such as mastitis (Mallard et al., 1998). Previous research has demonstrated that gene expression ( Crookenden et al., 2016) and protein concentrations (Kurpinska et al., 2016; Lippolis et al., 2006) are altered by periparturient immunosuppression. The reduction in plasma proteins in the periparturient cows in the current study supports previous reports of immunosuppression around the periparturient period (Figure 2). Furthermore, age and parity have also been associated with altered gene expressions and protein concentrations in plasma (Koizumi et al., 2016). Differential gene expression was observed in cows with different parities in the current study (Table 2).

This study demonstrates that periparturient period and parity affects galectin expression in the blood of dairy cows. Galectins have been known to regulate conceptus survival, growth, and adhesion during implantation in ruminants (Lilian A Okumu et al., 2011; Spencer, Johnson, Bazer, \& Burghardt, 2004). Despite all these reports that have been gathered about galectins, 
knowledge of galectin expression in cow blood during the periparturient period is limited. Most of the previous research focuses on galectin expression in the endometrium, placenta and the uterus (Popovici et al., 2005; Satterfield et al., 2006; Sheldon et all., 2009; Spencer et al., 2004). In this study, we provide evidence that galectins are also differentially expressed in cow blood. The results of this research open a whole new window into the interplay of the various galectins and how we can modulate them to improve the immune system of dairy cows, especially during the periparturient period.

The results of the current study demonstrate that $L G A L S 1,2,3,4,8,9,12$ and 15 are expressed in cow blood, and their expression is partly modulated during the periparturient period depending on the number of parity of the cow. Also, the periparturient stage, as well as the number of parities of the animal affects its expression in blood.

Although various studies have evaluated the expression of inflammation markers during the peripartal period (Bertoni et al., 2008; Crookenden et al., 2016; Li et al., 2016; Osorio et al., 2013; Osorio et al., 2014), to our knowledge, galectin gene expression in the blood of cows during the peripartal period has not been reported. Galectins have been established as biomarkers in various immunocompromised situations in both ruminants and non-ruminants (Labrie, et al., 2017; Madrigal-Matute et al., 2014).

\subsection{Galectin Genes Are Differentially Expressed in the Periparturient Period}

The results of this study show that 2 prototypes of the galectin family LGALS1 and LGALS15 were not detected after parturition regardless of the parity stage, indicating that they may play roles that were curtailed after parturition.

Galectin 1 is widely distributed in different tissues including innate and adaptive immune compartments and sites of tissue inflammation in both ruminants and non-ruminants (Cerliani et al., 2011). It is known to have both growth and immunomodulatory activities. LGALS1 has been known to suppresses autoimmune inflammation and apoptosis (Grassadonia et al., 2002). The presence of Galectin 1 close to parturition could be for the reduction of inflammatory activities during this time. Moreover, since LGALS1 has been associated with fetomaternal tolerance (Blois et al., 2007) during pregnancy, it is also noteworthy that its expression may be reduced a few days after calving as there is no fetus inside the mother anymore. Thus, $L G A L S 1$ may play a role before parturition to ensure homeostasis. Hence LGALS1 expression is essential to the health of both the fetus and the mother especially getting close to parturition in dairy cows as well.

Studies have implicated LGALS15 with cell growth, differentiation, and apoptosis, as well as in cell adhesion, chemoattraction, and migration(Farmer et al., 2007; Lewis et al., 2007; R. Y. Yang \& F. T. Liu, 2003). Other studies have shown that LGALS15 plays a significant role in the maintenance of healthy pregnancy in ruminants(Gray et al., 2006). Despite this available evidence, the role that Galectin 15 plays in the health of the dairy cows during the periparturient period has not been reported. In the current study, we detected LGALS15 in the blood of cows 14 days prepartum. This could mean that LGALS15, like LGALS1, could play a role in the immune function and the health of the pregnancy of dairy cows close to parturition but not after.

$L G A L S 2$ a prototype member of the galectin family was absent in $1^{\text {st }}$ parity cows but present 
in $2^{\text {nd }}$ and $3^{\text {rd }}$ parity cows. LGALS2 was also increased in $2^{\text {nd }}$ parity cows. Research has shown that $L G A L S 2$ induces apoptosis in activated T cells (Sturm et al., 2004). This could mean that $L G A L S 2$ may play a key role in the anti-inflammatory activities and immune responses of cows after parturition, but the extent of their actions may depend on the number of parities of the cow. This is understandable since cows with different parities have different immune statuses as reported by Ohtsuka et al. (H. Ohtsuka et al., 2010). Also, since the reproductive tract of the cow is exposed during parturition, LGALS2 expression could be essential in the restoration of homeostasis after an influx of immune cells to the site of infection.

$L G A L S 3$, the only chimera type galectin was expressed both pre and post-calving in cow blood. Galectin 3 expression did not change in cows in first and third parities. However, there was an increase in $2^{\text {nd }}$ parity cows. This also underscores the fact that, cows with different parities have different immune statuses during the periparturient period (Moosavi et al., 2014). $L G A L S 3$ has been shown to intervene in many cellular processes in vitro. Also, LGALS3 is up-regulated during inflammation/infection (Ochieng, Leite-Browning, \& Warfield, 1998). This could mean that $2^{\text {nd }}$ parity cows remain inflamed even seven days after calving. Recent research by our group demonstrated that peripartal cows supplemented with methionine had reduced levels of LGALS3 in their neutrophils (unpublished). This highlights the possible pro-inflammatory role of Galectin 3 in peripartal cows.

$L G A L S 4$, a tandem repeat was also expressed close to parturition and undetected seven days after calving in only $1^{\text {st }}$ and $3^{\text {rd }}$ parity cows. However, they were still present in $2^{\text {nd }}$ parity cows but their expression did not change after birth. In non-ruminants, LGALS4(unlike $L G A L S 1$ and $L G A L S 3$ which are ubiquitous) is only expressed in inflamed cells. Therefore, there is more restricted distribution of LGALS4 in normal tissues, but clear induction in early stages of malignancies renders it particularly promising as a diagnostic and prognostic biomarker. Since galectin 4 has been linked with infectious diseases, their reduction in expression in these animals after parturition could be a positive sign that the animals are in good health. However, it will be important to investigate whether blocking activities of LGALS4, in overexpressed conditions, would deliver critical therapeutic effects for the cow.

LGALS9 gene expression was increased in the blood of $2^{\text {nd }}$ parity cowsi. In the $1^{\text {st }}$ and $3^{\text {rd }}$ parity cows, however, they were present both before and after parturition but fold change in gene expression did not change. Galectin 9 in immunological contexts can influence the immune system in different ways, either by exacerbating the inflammatory process or by acting as an anti-inflammatory agent (Meggyes et al., 2014). Gal-9 preferentially induces apoptosis of activated CD4-positive $\mathrm{T}$ cells through $\mathrm{Ca}^{+}$influx-calpain-caspasel pathway. It has been demonstrated that Gal-9 is a ligand of $\mathrm{T}$ cell immunoglobulin- and mucin-domain-containing molecule 3 (TIM-3) and that Gal-9 induces apoptosis of TIM-3-expressing cells in vitro and in vivo (Nagahara et al., 2008). Previous research has suggested that Gal-9/TIM-3 pathway could play an important role in the immunoregulation and the altered Gal-9 and TIM-3 expression could result in an enhanced systemic inflammatory response (Miko et al., 2013). This makes the regulation of LGALS9 expression especially during this immunosuppressed stage of the animals very critical. In this regard, it is possible that galectin- 9 could play an important role in the regulation of maternal immune 
tolerance toward the fetus and may be a potent regulator of the adaptive and innate immune responses (Chabtini et al., 2013). Although data about the role of galectin-9 in the pathogenesis of diseases is emerging their possible role during cow pregnancy is not precisely known.

It was also interesting to find that LGALS12, which is involved in adipocyte differentiation was also expressed in cow blood. It was affected by both the periparturient period as well as the parity stage. Gal-12 promotes cell death of adipocytes. Previous studies have shown that an increase in the number of apoptotic cells in adipose tissue causes an increase in the level of galectin-12 mRNA (K. Hotta et al., 2001). The fact that LGALS12 is expressed in blood is noteworthy because in non-ruminants it is an adipose-expressed galectin-like molecule that participates in adipocyte apoptosis(K. Hotta et al., 2001; Hsu, Yang, \& Liu, 2006; R. Y. Yang $\&$ F. T. Liu, 2003). The possible biologic role of Gal-12 in cow blood needls to be explored.

\subsection{Periparturient Period Affects Gal-1, -2, -3, -4, -7, -8, 9 and Gal 12 Concentrations in} Plasma

Galectins are best known for their role outside cells following their secretion in the extracellular space via a non-classical pathway (Dai et al., 2005; Jeng, Frigeri, \& Liu, 1994; Jung et al., 2007; Madrigal-Matute et al., 2014; Maftouh et al., 2014; Markowska, Jefferies, \& Panjwani, 2011). Hence, it was imperative to investigate their secretion in plasma especially during this time of immunosuppression.

In a previous study, galectin-1 deficient mice showed higher rates of fetal loss which was corrected by treatment with recombinant Gal-1 to prevent fetal loss and restore tolerance. Our results showing higher Gal-1 concentration in plasma of periparturient cows in comparison with the control underscores its involvement in immunoregulation during pregnancy as reported previously by Blois et al. (Blois et al., 2007).

In contrast to Gal-1, research on the role of other less well-known galectins, especially Gal-2 and -12 , outside the cells is just in its infancy. However, it is already clear that they do exert a regulatory function in immune cells and have strong potential as biomarkers (Kikuko Hotta et al., 2001; Stowell et al., 2007; Wan, Yang, \& Liu, 2018; R.-Y. Yang \& F.-T. Liu, 2003). The results of the current study show that Gal-2 and Gal-12, which are both involved in apoptosis and homeostasis are significantly reduced in plasma of periparturient cows. Their reduction in concentration during the periparturient period could be a contributing factor to immunosuppression around this time. Furthermore, the results of the study also show that Gal-3 is reduced during the periparturient period in cow plasma (Figure 3). The decrease in Gal-3 concentration could be an indication of reduced inflammatory activity since it is an established biomarker of inflammation (Newlaczyl \& Yu, 2011).

Gal- 8 is a tandem-repeat galectin expressed in different organs and tissues under physiological or pathological conditions (Thurston, Wandel, von Muhlinen, Foeglein, \& Randow, 2012). Gal-8 modulates neutrophil function, migration and microbial killing (Nishi et al., 2003). Gal-8 plays a role not only in innate immunity but also in acquired immunity by inducing dendritic cell maturation and promoting Th1 immune responses (Dai et al., 2005). There is evidence that genes involved in extracellular matrix adhesion including LGALS8 are downregulated during the periparturient period, and this disrupts neutrophil migration and 
phagocytic capacity on the day of calving (Mitchell et al., 2014). On the contrary, in the current study, Gal-8 plasma concentration was increased in periparturient cows. This indicates that the capacity of neutrophils to migrate into the target tissue and their ability to kill pathogens is possibly also increased.

In the case of gal-9 in particular, its circulating levels have been investigated in humans with immune disorders or during infections (Labrie et al., 2017). These increase in galectin-9 concentration post calving indeed provide the impetus for future investigations on the correlation between plasma levels of gal-9 and immune status of dairy cows.

\section{Conclusion}

The results demonstrate that the periparturient period, as well as parity differentially, modulates transcription of mRNA and secretion of galectins in cow blood. Elucidation of the relationship between the periparturient period and galectin expression may help to define their roles in post partal diseases as well as aid in drug design in the dairy industry.

\section{Acknowledgement}

The authors would like to offer their sincere gratitude to Mr. Jeff Gundy of Michigan State University for collecting and sending us the blood samples used in this research. Special thanks also go to Mr. Corey Burgess of the North Carolina A \& T State University Dairy unit for helping with blood collection from the control animals. We would also like to thank Dr. Hamid Ismail for his assistance as well as members of the Laboratory of Genomic Diversity and Animal Biotechnology. Finally, National Institute of Food and Agriculture. Evans Allen funds for funding this research.

\section{References}

Adjei-Fremah, S., Asiamah, E. K., Ekwemalor, K., Jackai, L., Schimmel, K., \& Worku, M. (2016). Modulation of Bovine Wnt Signaling Pathway Genes by Cowpea Phenolic Extract. Journal of Agricultural Science, 8(3), 21. https://doi.org/10.5539/jas.v8n3p21

Adjei-Fremah, S., Ekwemalor, K., Asiamah, E., Ismail, H., \& Worku, M. (2016). Transcriptional profiling of the effect of lipopolysaccharide (LPS) pretreatment in blood from probiotics-treated dairy cows. Genomics data, 10, 15-18. https://doi.org/10.1016/j.gdata.2016.08.016

Adjei-Fremah, S., Jackai, L. E., Schimmel, K., \& Worku, M. (2016). Microarray analysis of the effect of Cowpea (Vigna unguiculata) phenolic extract in bovine peripheral blood. Journal of Applied Animal Research, 1-7.

Adjei-Fremah, S., Ekwemalor, K., Asiamah, E. K., Ismail, H., Ibrahim, S., \& Worku, M. (2018). Effect of probiotic supplementation on growth and global gene expression in dairy cows. Journal of Applied Animal Research, 46(1), 257-263. https://doi.org/10.1080/09712119.2017.1292913

Adjei-Fremah, S., Jackai, L. E., \& Worku, M. (2015). Analysis of phenolic content and antioxidant properties of selected cowpea varieties tested in bovine peripheral blood. American Journal of Animal and Veterinary Sciences, 10(4), 235-245. https://doi.org/10.3844/ajavsp.2015.235.245

Asiamah, E., Adjei-Fremah, S., Ekwemalor, K., Osei, B., Ismail, H., \& Worku, M. (2017). 
338 The effect of stage of lactation and parturition on galectin expression in cow blood. Journal of Animal Science, 95(supplement 4), 167-167. https://doi.org/10.2527/asasann.2017.338

Asiamah, E. K., Adjei-Fremah, S., Ekwemalor, K., \& Worku, M. (2016). Nystatin Modulates Genes in Immunity and Wingless Signaling Pathways in Cow Blood. Journal of Molecular Biology Research, 7(1), 1. https://doi.org/10.5539/jmbr.v7n1p1

Asiamah, E. K., Adjei-Fremah, S., Osei, B., Ekwemalor, K., \& Worku, M. (2016). An extract of Sericea Lespedeza modulates production of inflammatory markers in pathogen associated molecular pattern (PAMP) activated ruminant blood. Journal of Agricultural Science, 8(9), 1. https://doi.org/10.5539/jas.v8n9p1

Asiamah, E. K. (2015). Ex Vivo Effects of Water Extracts of Sericea Lespedeza on Cow, Sheep and Goat Blood (Doctoral dissertation, North Carolina Agricultural and Technical State University).

Bertoni, G., Trevisi, E., Han, X., \& Bionaz, M. (2008). Effects of inflammatory conditions on liver activity in puerperium period and consequences for performance in dairy cows. $J$ Dairy Sci, 91(9), 3300-3310. https://doi.org/10.3168/jds.2008-0995

Bianchi, M. E. (2007). DAMPs, PAMPs and alarmins: all we need to know about danger. Journal of leukocyte biology, 81(1), 1-5. https://doi.org/10.1189/jlb.0306164

Blois, S. M., Ilarregui, J. M., Tometten, M., Garcia, M., Orsal, A. S., Cordo-Russo, R., ... Arck, P. C. (2007). A pivotal role for galectin-1 in fetomaternal tolerance. Nature Medicine, 13, 1450. https://doi.org/10.1038/nm1680

Cerliani, J. P., Stowell, S. R., Mascanfroni, I. D., Arthur, C. M., Cummings, R. D., \& Rabinovich, G. A. (2011). Expanding the universe of cytokines and pattern recognition receptors: galectins and glycans in innate immunity. J Clin Immumol, 31(1), 10-21. https://doi.org/10.1007/s10875-010-9494-2

Chabtini, L., Mfarrej, B., Mounayar, M., Zhu, B., Batal, I., Dakle, P. J., ... Guleria, I. (2013). TIM-3 regulates innate immune cells to induce fetomaternal tolerance. J Immunol, 190(1), 88-96. https://doi.org/10.4049/jimmunol.1202176

Crookenden, M., Heiser, A., Murray, A., Dukkipati, V., Kay, J., Loor, J., ... Walker, C. (2016). Parturition in dairy cows temporarily alters the expression of genes in circulating neutrophils. Journal of dairy Science, 99(8), 6470-6483. https://doi.org/10.3168/jds.2015-10877

Dai, S.-Y., Nakagawa, R., Itoh, A., Murakami, H., Kashio, Y., Abe, H., ... Hirashima, M. (2005). Galectin-9 Induces Maturation of Human Monocyte-Derived Dendritic Cells. The Journal of Immunology, 175(5), 2974-2981. https://doi.org/10.4049/jimmunol.175.5.2974

Ekwemalor, K., Asiamah, E., Adjei-Fremah, S., \& Worku, M. (2016). Effect of a mushroom (Coriolus versicolor) based probiotic on goat health. Am J Anim Vet Sci, 11(3), 108-118. https://doi.org/10.3844/ajavsp.2016.108.118

Ekwemalor, K., Asiamah, E., \& Worku, M. (2016). Effect of a mushroom (Coriolus versicolor) based probiotic on the expression of toll-like receptors and signal transduction in goat neutrophils. Journal of Molecular Biology Research, 6(1), 71. 
https://doi.org/10.5539/jmbr.v6n1p71

Esposito, G., Irons, P. C., Webb, E. C., \& Chapwanya, A. (2014). Interactions between negative energy balance, metabolic diseases, uterine health and immune response in transition dairy cows. Animal Reproduction Science, 144(3-4), 60-71. https://doi.org/10.1016/j.anireprosci.2013.11.007

Farmer, J., Burghardt, R., Jousan, D., Hansen, P., Bazer, F., \& Spencer, T. (2007). Galectin 15 (LGALS15) is a mediator of trophoblast attachment in the ovine uterus. Paper presented at the Biology of reproduction. https://doi.org/10.1093/biolreprod/77.s1.204b

Fermino, M. L., Polli, C. D., Toledo, K. A., Liu, F. T., Hsu, D. K., Roque-Barreira, M. C., ... Halbwachs-Mecarelli, L. (2011). LPS-induced galectin-3 oligomerization results in enhancement of neutrophil activation. PloS one, 6(10), e26004. https://doi.org/10.1371/journal.pone.0026004

Grassadonia, A., Tinari, N., Iurisci, I., Piccolo, E., Cumashi, A., Innominato, P., ... Iacobelli, S. (2002). 90K (Mac-2 BP) and galectins in tumor progression and metastasis. Glycoconjugate journal, 19(7), 551-556. https://doi.org/10.1023/B:GLYC.0000014085.00706.d4

Gray, C. A., Abbey, C. A., Beremand, P. D., Choi, Y., Farmer, J. L., Adelson, D. L., ...Spencer, T. E. (2006). Identification of endometrial genes regulated by early pregnancy, progesterone, and interferon tau in the ovine uterus. Biol Reprod, 74(2), 383-394.

Heiser, A., McCarthy, A., Wedlock, N., Meier, S., Kay, J., Walker, C., ... Watkins, K. (2015). Grazing dairy cows had decreased interferon- $\gamma$, tumor necrosis factor, and interleukin-17, and increased expression of interleukin-10 during the first week after calving. Journal of dairy Science, 98(2), 937-946. https://doi.org/10.3168/jds.2014-8494

Hotta, K., Funahashi, T., Matsukawa, Y., Takahashi, M., Nishizawa, H., Kishida, K., ... Nakamura, T. (2001). Galectin-12, an adipose-expressed galectin-like molecule possessing apoptosis-inducing activity. Journal of Biological Chemistry, 276(36), 34089-34097. https://doi.org/10.1074/jbc.M105097200

Hsu, D. K., Yang, R. Y., \& Liu, F. T. (2006). Galectins in apoptosis. Methods Enzymol, 417, 256-273. https://doi.org/10.1016/S0076-6879(06)17018-4

Jeng, K. C. G., Frigeri, L. G., \& Liu, F.-T. (1994). An endogenous lectin, galectin-3 $(\epsilon \mathrm{BP} / \mathrm{Mac}-2)$, potentiates IL-1 production by human monocytes. Immunology letters, 42(3), 113-116. https://doi.org/10.1016/0165-2478(94)90072-8

Jung, E. J., Moon, H. G., Cho, B. I., Jeong, C. Y., Joo, Y. T., Lee, Y. J., ... Kim, J. W. (2007). Galectin - 1 expression in cancer - associated stromal cells correlates tumor invasiveness and tumor progression in breast cancer. International journal of cancer, 120(11), 2331-2338. https://doi.org/10.1002/ijc.22434

Kehrli, M. E., Nonnecke, B. J., \& Roth, J. A. (1989). Alterations in bovine neutrophil function during the periparturient period. Am. J. Vet. Res, 50(2), 207-214.

Koizumi, M., Nahar, A., Yamabe, R., \& Kadokawa, H. (2016). Positive correlations of age and parity with plasma concentration of macrophage migration inhibitory factor in Japanese 
black cows. Journal of Reproduction and Development, 62(3), 257-263. https://doi.org/10.1262/jrd.2015-144

Kurpinska, A. K., Jarosz, A., Ozgo, M., \& Skrzypczak, W. F. (2016). Analysis of protein expression changes in the blood plasma of cows during the last month before parturition and 2 months after calving. Turkish Journal of Biology, 40(1), 206-216. https://doi.org/10.3906/biy-1501-30

Labrie, M., De Araujo, L. O. F., Communal, L., Mes-Masson, A.-M., \& S.t-Pierre, Y. (2017). Tissue and plasma levels of galectins in patients with high grade serous ovarian carcinoma as $\begin{array}{lllll}\text { new predictive biomarkers. Scientific Reports, } & 7(1), \quad 13244 .\end{array}$ https://doi.org/10.1038/s41598-017-13802-5

Lewis, S. K., Farmer, J. L., Burghardt, R. C., Newton, G. R., Johnson, G. A., Adelson, D. L., ... Spencer, T. E. (2007). Galectin 15 (LGALS15): A gene uniquely expressed in the uteri of sheep and goats that functions in trophoblast attachment. Biology of reproduction, 77(6), 1027-1036. https://doi.org/10.1095/biolreprod.107.063594

Li, C., Batistel, F., Osorio, J. S., Drackley, J. K., Luchini, D., \& Loor, J. J. (2016). Peripartal rumen-protected methionine supplementation to higher energy diets elicits positive effects on blood neutrophil gene networks, performance and liver lipid content in dairy cows. J Anim Sci Biotechnol, 7(1), 18. https://doi.org/10.1186/s40104-016-0077-9

Lippolis, J. D., Peterson-Burch, B. D., \& Reinhardt, T. A. (2006). Differential expression analysis of proteins from neutrophils in the periparturient period and neutrophils from dexamethasone-treated dairy cows. Veterinary immunology and immunopathology, 111(3-4), 149-164. https://doi.org/10.1016/j.vetimm.2005.12.001

Livak, K. J., \& Schmittgen, T. D. (2001). Analysis of relative gene expression data using real-time quantitative PCR and the 2- $\Delta \Delta \mathrm{CT}$ method. methods, 25(4), 402-408. https://doi.org/10.1006/meth.2001.1262

Madrigal-Matute, J., Lindholt, J. S., Fernandez-Garcia, C. E., Benito-Martin, A., Burillo, E., Zalba, G., ... Egido, J. (2014). Galectin-3, a biomarker linking oxidative stress and inflammation with the clinical outcomes of patients with atherothrombosis. Journal of the American Heart Association, 3(4), e000785. https://doi.org/10.1161/JAHA.114.000785

Maftouh, M., Belo, A. I., Avan, A., Funel, N., Peters, G. J., Giovannetti, E., \& van Die, I. (2014). Galectin-4 expression is associated with reduced lymph node metastasis and modulation of Wnt/ $\beta$-catenin signalling in pancreatic adenocarcinoma. Oncotarget, 5(14), 5335. https://doi.org/10.18632/oncotarget.2104

Mallard, B., Dekkers, J., Ireland, M., Leslie, K., Sharif, S., Vankampen, C. L., ... Wilkie, B. (1998). Alteration in immune responsiveness during the peripartum period and its ramification on dairy cow and calf health. Journal of dairy Science, 81(2), 585-595. https://doi.org/10.3168/jds.S0022-0302(98)75612-7

Markowska, A. I., Jefferies, K. C., \& Panjwani, N. (2011). Galectin-3 protein modulates cell surface expression and activation of vascular endothelial growth factor receptor 2 in human endothelial cells. Journal of Biological Chemistry, 286(34), 29913-29921. https://doi.org/10.1074/jbc.M111.226423 
Masahiro, S., Hashiba, K., Junko, N.-K., \& Okuda, K. (2015). The luteotrophic function of galectin-1 by binding to the glycans on vascular endothelial growth factor receptor-2 in bovine luteal cells. Journal of Reproduction and Development, 61(5), 439-448. https://doi.org/10.1262/jrd.2015-056

Meggyes, M., Miko, E., Polgar, B., Bogar, B., Farkas, B., Illes, Z., \& Szereday, L. (2014). Peripheral blood TIM-3 positive NK and CD8+ $\mathrm{T}$ cells throughout pregnancy: TIM-3/galectin-9 interaction and its possible role during pregnancy. PloS one, 9(3), e92371. https://doi.org/10.1371/journal.pone.0092371

Miko, E., Meggyes, M., Bogar, B., Schmitz, N., Barakonyi, A., Varnagy, A., ... Szereday, L. (2013). Involvement of Galectin-9/TIM-3 pathway in the systemic inflammatory response in early-onset preeclampsia. PloS one, 8(8), e71811. https://doi.org/10.1371/journal.pone.0071811

Mitchell, M., Morgan, S., Moyes, K., Murray, A., Walker, C., \& Roche, J. (2014). Parturition in dairy cows temporarily alters the expression of genes involved in neutrophil attachment. Paper presented at the Proceedings of the 5th Australasian Dairy Science Symposium.

Moosavi, M., Mirzaei, A., Ghavami, M., \& Tamadon, A. (2014). Relationship between season, lactation number and incidence of clinical mastitis in different stages of lactation in a Holstein dairy farm. Paper presented at the Veterinary research forum: an international quarterly journal.

Nagahara, K., Arikawa, T., Oomizu, S., Kontani, K., Nobumoto, A., Tateno, H., ... Hirashima, M. (2008). Galectin-9 increases Tim-3+ dendritic cells and CD8+ T cells and enhances antitumor immunity via galectin-9-Tim-3 interactions. J Immunol, 181(11), 7660-7669. https://doi.org/10.4049/jimmunol.181.11.7660

Newlaczyl, A. U., \& Yu, L. G. (2011). Galectin-3--a jack-of-all-trades in cancer. Cancer Lett, 313(2), 123-128. https://doi.org/10.1016/j.canlet.2011.09.003

Nio-Kobayashi, J., Hashiba, K., Sano, M., Okuda, K., Duncan, W. C., \& Iwanaga, T. (2016). Expression Profiles and Possible Roles of Galectins in the Corpus Luteum. Trends in Glycoscience and Glycotechnology, 28(162), E71-E77. https://doi.org/10.4052/tigg.1416.1E

Nishi, N., Shoji, H., Seki, M., Itoh, A., Miyanaka, H., Yuube, K., ... Nakamura, T. (2003). Galectin-8 modulates neutrophil function via interaction with integrin $\alpha \mathrm{M}$. Glycobiology, 13(11), 755-763. https://doi.org/10.1093/glycob/cwg102

Ochieng, J., Leite-Browning, M. L., \& Warfield, P. (1998). Regulation of cellular adhesion to extracellular matrix proteins by galectin-3. Biochem Biophys Res Commun, 246(3), 788-791. https://doi.org/10.1006/bbrc. 1998.8708

Ohtsuka, H., Terasawa, S., Watanabe, C., Kohiruimaki, M., Mukai, M., Ando, T., ... Morris, S. (2010). Effect of parity on lymphocytes in peripheral blood and colostrum of healthy Holstein dairy cows. Canadian Journal of Veterinary Research-Revue Canadienne De Recherche Veterinaire, 74(2), 130-135.

Ohtsuka, H., Uematsu, M., Saruyama, Y., Ono, M., Kohiruimaki, M., Ando, T., \& Kawamura, S. (2009). Age-related alterations in peripheral leukocyte population of healthy Holstein dairy 
cows during the pre-calving period. Journal of Veterinary Medical Science, 71(8), 1121-1124. https://doi.org/10.1292/jvms.71.1121

Okumu, L. A., Fair, T., Szekeres-Bartho, J., O'Doherty, A. M., Crowe, M. A., Roche, J. F., ... Forde, N. (2011). Endometrial expression of progesterone-induced blocking factor and galectins-1,-3,-9, and-3 binding protein in the luteal phase and early pregnancy in cattle. Physiological genomics, $\quad$ 43(14), 903-910. https://doi.org/10.1152/physiolgenomics.00251.2010

Okumu, L. A., Fair, T., Szekeres-Bartho, J., O'Doherty, A. M., Crowe, M. A., Roche, J. F., ... Forde, N. (2011). Endometrial expression of progesterone-induced blocking factor and galectins-1, $-3,-9$, and -3 binding protein in the luteal phase and early pregnancy in cattle. Physiol Genomics, 43(14), 903-910. https://doi.org/10.1152/physiolgenomics.00251.2010

Oltenacu, P., \& Ekesbo, I. (1994). Epidemiological study of clinical mastitis in dairy cattle. Veterinary research, 25(2-3), 208-212.

Osei, B., Worku, M., Adjei-Fremah, S., Asiamah, E., Ekwemalor, K., \& Ismail, H. (2017). 040 Expression galectins in sheep blood during the periparturient period. Journal of Animal Science, 95(supplement4), 20-20. https://doi.org/10.2527/asasann.2017.040

Osorio, J. S., Ji, P., Drackley, J. K., Luchini, D., \& Loor, J. J. (2013). Supplemental Smartamine $\mathrm{M}$ or MetaSmart during the transition period benefits postpartal cow performance and blood neutrophil function. $J$ Dairy Sci, 96(10), 6248-6263. https://doi.org/10.3168/jds.2012-5790

Osorio, J. S., Trevisi, E., Ji, P., Drackley, J. K., Luchini, D., Bertoni, G., \& Loor, J. J. (2014). Biomarkers of inflammation, metabolism, and oxidative stress in blood, liver, and milk reveal a better immunometabolic status in peripartal cows supplemented with Smartamine $\mathrm{M}$ or MetaSmart. J Dairy Sci, 97(12), 7437-7450. https://doi.org/10.3168/jds.2013-7679

Popovici, R. M., Krause, M. S., Germeyer, A., Strowitzki, T., \& von Wolff, M. (2005). Galectin-9: a new endometrial epithelial marker for the mid-and late-secretory and decidual phases in humans. The Journal of Clinical Endocrinology \& Metabolism, 90(11), 6170-6176. https://doi.org/10.1210/jc.2004-2529

Sato, S., St - Pierre, C., Bhaumik, P., \& Nieminen, J. (2009). Galectins in innate immunity: dual functions of host soluble $\beta$-galactoside - binding lectins as damage - associated molecular patterns (DAMPs) and as receptors for pathogen - associated molecular patterns $\begin{array}{llll}\text { (PAMPs). Immunological } & \text { reviews, } & \text { 230(1), }\end{array}$ https://doi.org/10.1111/j.1600-065X.2009.00790.X

Satterfield, M. C., Bazer, F. W., \& Spencer, T. E. (2006). Progesterone regulation of preimplantation conceptus growth and galectin 15 (LGALS15) in the ovine uterus. Biology of reproduction, 75(2), 289-296. https://doi.org/10.1095/biolreprod.106.0529.44

Sheldon, I. M., Cronin, J., Goetze, L., Donofrio, G., \& Schuberth, H.-J. (2009). Defining postpartum uterine disease and the mechanisms of infection and immunity in the female reproductive tract in cattle. Biology of reproduction, 81(6), 1025-1032. https://doi.org/10.1095/biolreprod.109.077370 
Sordillo, L. M., \& Mavangira, V. (2014). The nexus between nutrient metabolism, oxidative stress and inflammation in transition cows. Animal Production Science, 54(9), 1204-1214. https://doi.org/10.1071/AN14503

Souza, B. M., Lambert, S. M., Nishi, S. M., Benavides, M. V., Berne, M. E., Madruga, C. R., $\&$ Almeida, M. A. (2015). Galectins and collectinis expression are increased in Haemonchus contortus-infected corriedale sheep. Rev Bras Parasitol Vet, 24(3), 317-323. https://doi.org/10.1590/S1984-29612015056

Spencer, T. E., Johnson, G. A., Bazer, F. W., \& Burghardt, R. C. (2004). Implantation mechanisms: insights from the sheep. Reproduction, 128(6), 657-668. https://doi.org/10.1530/rep. 1.00398

Stowell, S. R., Karmakar, S., Stowell, C. J., Dias-Baruffi, M., McEver, R. P., \& Cummings, R. D. (2007). Human galectin-1,-2, and-4 induce surface exposure of phosphatidylserine in activated human neutrophils but not in activated T cells. Blood, 109(1), 219-227. https://doi.org/10.1182/blood-2006-03-007153

Sturm, A., Lensch, M., Andre, S., Kaltner, H., Wiedenmann, B., Rosewicz, S., ... Gabius, H. J. (2004). Human galectin-2: novel inducer of T cell apoptosis with distinct profile of caspase activation. $J$ Immunol, 173(6), 3825-3837. https://doi.org/10.4049/jimmunol.173.6.3825

Thurston, T. L., Wandel, M. P., von Muhlinen, N., Foeglein, Á., \& Randow, F. (2012). Galectin-8 targets damaged vesicles for autophagy to defend cells against bacterial invasion. Nature, 482(7385), 414. https://doi.org/10.1038/nature10744

van Kooyk, Y., \& Rabinovich, G. A. (2008). Protein-glycan interactions in the control of innate and adaptive immune responses. Nat Immunol, 9(6), 593-601. https://doi.org/10.1038/ni.f.203

Walker, C. G., Meier, S., Littlejohn, M. D., Lehnert, K., Roche, J. R., \& Mitchell, M. D. (2010). Modulation of the maternal immune system by the pre-implantation embryo. BMC Genomics, 11(1), 474. https://doi.org/10.1186/1471-2164-11-474

Wan, L., Yang, R.-Y., \& Liu, F.-T. (2018). Galectin-12 in Cellular Differentiation, Apoptosis and Polarization. International journal of molecular sciences, 19(1), 176. https://doi.org/10.3390/ijms19010176

Worku, M., Abdalla, A., Adjei-Fremah, S., \& Ismail, H. (2016). The impact of diet on expression of genes involved in innate immunity in goat blood. Journal of Agricultural Science, 8(3), 1-9. https://doi.org/10.5539/jas.v8n3p1

Worku, M., \& Morris, A. (2009). Binding of different forms of lipopolysaccharide and gene expression in bovine blood neutrophils. Journal of dairy science, 92(7), 3185-3193. https://doi.org/10.3168/jds.2008-1905

Yang, R.-Y., \& Liu, F.-T. (2003). Galectins in cell growth and apoptosis. Cellular and molecular life sciences, 60(2), 267-276. https://doi.org/10.1007/s000180300022

Zhang, L., Xia, Y., Tang, F., Li, S. J., Yang, L., \& Wang, B. (2015). The regulation of intrauterine immune cytokines and chemokines during early pregnancy in the bovine. Large Animal Review, 21(1), 23-31. 


\section{Macrothink

\section{Copyright Disclaimer}

Copyright reserved by the author(s).

This article is an open-access article distributed under the terms and conditions of the Creative Commons Attribution license (http://creativecommons.org/licenses/by/3.0/). 